\section{KEWENANGAN PEMERINTAH DALAM MENGELOLAH WILAYAH LAUT MENURUT UNDANG-UNDANG NOMOR 23 TAHUN 2014 TENTANG PEMERINTAHAN DAERAH ${ }^{1}$} Oleh : Firda Nadia Nadjib ${ }^{2}$

\begin{abstract}
ABSTRAK
Tujuan dilakukannya penelitian ini adalah untuk mengetahui bagaimana bentuk kewenangan pemerintah daerah dalam Sistem Ketatanegaraan Indonesia dan bagaimana kewenangan Pemerintah Daerah dalam mengatur wilayah laut menurut UU No. 23 Tahun 2014 tentang Pemerintahan Daerah. Dengan menggunakan metode penelitian yuridis normatif, disimpulkan: 1. Urusan pemerintahan yang menjadi kewenangan Pemerintah daerah Kabupaten/Kota adalah urusan pemerintahan yang lokasinya dalam daerah kabupaten/kota, urusan pemerintahan yang penggunanya dalam Daerah kabupaten/kota, urusan pemerintahan yang manfaat atau dampak negatifnya hanya dalam daerah kabupaten/kota dan/atau urusan Pemerintahan yang penggunaan sumber dayanya lebih efisien apabila dilakukan oleh Daerah kabupaten/kota. 2. Kewenangan Pemerintah Daerah dalam Mengelola wilayah Laut dalam Undang-undang Nomor 23 Tahun 2014 tentang Pemerintahan Daerah terdapat 7 (bidang) dalam mengelola dan mengatur wilayah laut yang termasuk urusan pemerintahan konkuren yang dimana urusan pemerintahan ini dibagi kewenangan terhadap pemerintah pusat dan pemerintah daerah, pemerintah pusat dan pemerintah provinsi mempunyai kewenangan dalamketujuh bidang dalam bidang kelautan dan perikanan, kewenangan pemerintah Provinsi dalam mengatur wilayah laut dalam Undang-undang tentang Pemerintahan Daerah Hanya sebatas dalam Laut territorial atau 12 mil sebagaimana yang ditentukan oleh Undang-Undang.

Kata kunci: Kewenangan, Mengelolah Wilayah Laut, Pemerintah Daerah
\end{abstract}

\section{PENDAHULUAN}

\section{A. Latar Belakang Masalah}

Pembagian urusan bidang antara pemerintah pusat, daerah provinsi dan daerah kabupaten/kota terkhusus pada sektor kelautan dan perikanan yang diatur oleh Undang-Undang tidak terdapat pemberian kewenangan pengelolaan kepada daerah kabupaten/kota yang diambil alih oleh pemerintah pusat dan daerah provinsi. Terdapat anggapan bahwa pemberian kewenangan hanya kepada pemerintah daerah provinsi tidak sesuai dengan maksud diberikannya otonomi yang seluas-luasnya kepada daerah yang diarahkan untuk mempercepat terwujudnya kesejahteraan masyarakat melalui peningkatan pelayanan, pemberdayaan, dan peran serta masyarakat. Terlebih substansi penting dari otonomi daerah adalah pelimpahan kewenangan dari pusat ke daerah secara politik dan ekonomi agar pembangunan dan pertumbuhan ekonomi berlangsung secara adil dan merata di daerah. ${ }^{3}$

Banyak masalah lain dapat muncul ketika hampir keseluruhan urusan daerah diurus oleh Pemerintah Pusat. Contoh: dalam hal database pesisir dan pulau-pulau kecil yang kewenangannya dilakukan oleh Pemerintah Pusat yang sebenarnya dapat diserahkan kepada Pemeritah Kabupaten/Kotayang wilayahnya akan dilakukan pendataan. Di sisi lain, pembagian kewenangan yang tidak seimbang dapat menurunkan Pendapatan Anggaran Daerah (PAD) dan juga ketika terjadi masalah di daerah terkait berbagai kebijakan yang ditangani oleh Pusat, penanganannya semua harus dilakukan oleh Pemerintah Pusat. ${ }^{4}$

Keresahan akan dampak negatif yang ditimbulkan UU Nomor 32 Tahun 2004 tentang Pemerintahan Daerah, menyebabkan pemberian penguatan status kepada posisi Pemerintah Daerah Provinsi sebagai kepanjangan tangan kekuasaan Pusat sebagai suatu daerah otonomi melalui UU No. 23 Tahun 2014 dengan menarik urusan-urusan yang selama ini ditangani oleh Pemerintah Daerah Kabupaten/Kota dengan alasan gubernur gagal mencegah abuse of power dari Pemerintah Daerah Kabupaten/Kota dan, terutama dalam

\footnotetext{
${ }^{3}$ Basri, Penataan dan pengelolaan wilayah kelautan, Vol XVIII No. 3, 2013, hlm. 182

${ }^{4} / \mathrm{bid}$, hlm. 183
} 
masalah pertambangan, kelautan, dan kehutanan, dan juga dengan alasan dampak negatif dari abuse of power tersebut yang mengakibatkan kerusakan lingkungan yang parah akibat eksploitasi Pemerintah Daerah Kabupaten/Kotadalam rangka meningkatkan pendapatan daerah mereka. ${ }^{5}$

Dalam hal pengelolaan kelautan dan perikanannya, terdapat alasan mengapa daerah harus tetap terlibat dalam pengelolaannya, hal ini disebabkan karena daerah tidak hanya menerima menjalankan kebijakan Provinsi dan Pusat saja karena yang mempunyai tempat/wilayah pengelolaan adalah Pemerintah Kabupaten/Kota. Pendekatan penarikan semua kekuasaan/kewenangan ini merupakan resentralisasi sebagian atau sentralisasi mikro yang pada kenyataannya menjauhkan masyarakat dari pihak berwenang daerah (birokrasi) yang seharusnya menangani masalah-masalah yang ada di daerah. Paradoks mengenai jarak ini akan menyebabkan ketidak efisienan dan hambatan bagi partisipasi publik dan pengawasan terhadap pemerintah. ${ }^{6}$

Terhadap pengelolaan kelautan di daerah, terdapat empat tipe/rezim kepemilikan SDA, yakni a.State property regimes, b.Public property regimes, c. Private property regimes, $\mathrm{d}$. Common property regimes (open acces). ${ }^{7}$ Masing-masing rezim kepemilikan atau penguasaan sumber daya ini turut menentukan bagaimana cara pengelolaannya dilakukan, oleh karenanya pembagian kewenangan antara Pemerintah Pusat dan Daerah hendaknya dilakukan dengan memperhatikan juga hak-hak masyarakat adat khususnya hak ulayat laut (sea tenure)yang diakui secara konstitusional dalam Pasal 18B ayat (2) UUD NRI 1945, terutama dalam pengaturan pengelolaanya yang saat ini mendapatkan pengaturannya dalam Pasal 29 ayat (5) UU No.23/2014.

\section{B. Rumusan Masalah}

1. Bagaimanakah bentuk kewenangan pemerintah daerah dalam Sistem Ketatanegaraan Indonesia?

\section{Ibid}

${ }^{6}$ http://www.thejakartapost.com/news/2014/12/22/overc oming-problems-new-autonomy-era.html diakses pada 27 Agustus 2019

7Daniel W. Bromley \& Michael Cernea, World Bank Discussion Papers, The Management of Common Property Natural Resources, hal. 11
2. Bagaimanakah kewenangan Pemerintah Daerah dalam mengatur wilayah laut menurut UU No. 23 Tahun 2014 tentang Pemerintahan Daerah?

\section{Metode Penelitian}

Karya tulis berebentuk skripsi ini menggunakan metode penelitian yuridis normatif untuk meneliti peraturan perundangundangan dan literatur yang berkaitan dengan permasalahan yang akan dibahas. Penelitian dilakukan hanya pada data sekunder yang diperoleh dari bahan-bahan kepustakaan seperti: Bahan hukum primer yaitu peraturan perundang-undangan. Bahan hukum sekunder yaitu: literatur dan karya-karya ilmiah hukum. Bahan hukum tersier, yaitu: kamus hukum dan kamus umum besar bahasa Indonesia.

Penelitian ini bersifat deskriptif analisis untuk memberikan gambaran mengenai permasalahan-permasalahan yang ada. Analisis terhadap bahan-bahan hukum secara kualitatifnormatif.

\section{PEMBAHASAN}

A. Kewenangan Pemerintah Daerah dalam Sistem Ketatanegaraan Indonesia

Pasal 1 ayat (1) Undang-Undang Dasar Negara Republik Indonesia Tahun 1945 menyatakan bahwa Negara Indonesia adalah negara kesatuan yang berbentuk republik. ${ }^{8}$ Konsekuensi logis sebagai Negara kesatuan adalah dibentuknya pemerintah Negara Indonesia sebagai pemerintah nasional untuk pertama kalinya dan kemudian pemerintah nasional tersebutlah yang kemudian membentuk Daerah sesuai ketentuan peraturan perundang-undangan. Kemudian Pasal 18 ayat (2) dan ayat (5) Undang-Undang Dasar Negara Republik Indonesia Tahun 1945 menyatakan bahwa Pemerintahan Daerah berwenang untuk mengatur dan mengurus sendiri Urusan Pemerintahan menurut Asas Otonomi dan Tugas Pembantuan dan diberikan otonomi yang seluas-luasnya.

Pemberian otonomi yang seluas-luasnya kepada Daerah diarahkan untuk mempercepat terwujudnya kesejahteraan masyarakat melalui peningkatan pelayanan, pemberdayaan, dan peran serta masyarakat. Di samping itu melalui

${ }^{8}$ Lihat Pasal 1 ayat (1) Undang-Undang Dasar Negara Republik Indonesia Tahun 1945 
otonomi luas, dalam lingkungan strategis globalisasi, Daerah diharapkan mampu meningkatkan daya saing dengan memperhatikan prinsip demokrasi, pemerataan, keadilan, keistimewaan dan kekhususan serta potensi dan keanekaragaman Daerah dalam sistem Negara Kesatuan Republik Indonesia.

Hubungan Pemerintah Pusat dengan Daerah dapat dilihat dari alinea ketiga dan keempat Pembukaan Undang-Undang Dasar Negara Republik Indonesia Tahun 1945. Alinea ketiga memuat pernyataan kemerdekaan bangsa Indonesia. Sedangkan alinea keempat memuat pernyataan bahwa setelah menyatakan kemerdekaan, yang pertama kali dibentuk adalah Pemerintah Negara Indonesia yaitu Pemerintah Nasional yang bertanggung jawab mengatur dan mengurus bangsa Indonesia. Lebih lanjut dinyatakan bahwa tugas Pemerintah Negara Indonesia adalah melindungi seluruh bangsa dan tumpah darah Indonesia, memajukan kesejahteraan umum dan mencerdaskan kehidupan bangsa serta ikut memelihara ketertiban dunia berdasarkan kemerdekaan, perdamaian abadi, dan keadilan sosial. ${ }^{9}$

Dalam mengatur dan mengurus Urusan Pemerintahan yang menjadi kewenangan Daerah tersebut, DPRD dan kepala daerah dibantu oleh Perangkat Daerah.Sebagai konsekuensi posisi DPRD sebagai unsur penyelenggara Pemerintahan Daerah maka susunan, kedudukan, peran, hak, kewajiban, tugas, wewenang, dan fungsi DPRD tidak diatur dalam beberapa undang-undang namun cukup diatur dalam Undang-Undang ini secara keseluruhan guna memudahkan pengaturannya secara terintegrasi.Berdasarkan UU Nomor 23 tahun 2014 klasifikasi urusan pemerintahan terdiri dari 3 urusan yakni urusan pemerintahan absolut, urusan pemerintahan konkuren, dan urusan pemerintahan umum, yang sebagaiamana dimaksud, adalah : $:^{10}$

a. Urusan pemerintahan absolut adalah Urusan Pemerintahan yang sepenuhnya menjadi kewenangan Pemerintah Pusat. Definisi Pusat jika kita masuk bidang

\footnotetext{
9 Lihat Penjelasan Umum Undang-undang Nomor 23 Tahun 2014 tentang Pemerintahan Daerah

10 Lihat Pasal 9 Undang-undang Nomor 23 Tahun 2014 tentang Pemerintahan Daerah
}

eksekutif adalah Pemerintah Pusat, definisinya sendiri adalah Presiden Republik Indonesia yang memegang kekuasaan pemerintahan Negara Republik Indonesia yang dibantu oleh Wakil Presiden dan menteri. Cakupan urusan pemerintahan absolut terdiri dari masalah bidang politik luar negeri, pertanahan, keamanan, yustisi, moneter dan fiskal serta agama.

Meski sepenuhnya berada ditangan pusat, urusan pemerintahan absolut bisa dilimpahkan kepada instansi vertikal yang ada di daerah berdasarkan asas dekonsentrasi Instansi vertical sendiri adalah perangkat kementerian dan/atau lembaga pemerintah nonkementerian yang mengurus Urusan Pemerintahan yang tidak diserahkan kepada daerah otonom dalam wilayah tertentu dalam rangka Dekonsentrasi, contoh instansi vertical di daerah adalah satuan kerja perangkat daerah atau SKPD, seperti dinas dan badan daerah

b. Urusan pemerintahan konkuren adalah urusan Pemerintahan yang dibagi antara Pemerintah Pusat dan Daerah provinsi dan Daerah kabupaten/ kota. Definisinya adalah urusan Pemerintahan yang dibagi antara Pemerintah Pusat dan Daerah provinsi dan Daerah kabupaten/kota, urusan yang diserahkan kepada daerah menjadi dasar pelaksana otonomi daerah. Pembagian itu mengyangkupi berbagai bidang, mulai dari pertanian, perdagangan, pertambangan, perikanan dll. Tapi prinsip utama dalam pembagian urusan pemerintahan konkuren adalah harus didasarkan pada akuntabilitas, efisiensi, eksternalitas serta harus berkepentingan nasional.

Pembagian urusan konkuren itu kemudian diperinci dalam tatananan territorial atau wilayah, seperti contohnya dalam lokasi, pusat berwenang pada lokasi lintasi Negara ataupun lintas daerah provinsi, sedang provinsi berada pada lintas kota/ kabupaten, sedang untuk tingkat kota/ kabupaten berada pada area dalam kota/ kabupaten.

c. Urusan pemerintahan umum adalah urusan Pemerintahan yang menjadi kewenangan Presiden sebagai kepala pemerintahan. definisinya adalah urusan pemerintahan 
yang menjadi kewenangan Presiden sebagai kepala Pemerintahan. Urusan ini meliputi pembinaan ketahanan nasional, kerukunan antar umatberagama, persatuan dan kesatuan bangsa, penanganan konflik sosial, pembinaan kerukunan antar suku ataupun intrasuku, koordinasi pelaksanaan tugas antarinstansi pemerintahan yang ada diwilayah daerah provinsi dan kota/ kabupaten, pengembangan kehidupan demokrasi dan, pelaksananan semua urusan pemerintahan yang bukan kewenangan daerah.

Pelaksaan urusan pemerintahan umum adalah gubernur dan walikota serta bupati di daerahnya masing-masing, dibantu oleh instansi vertical. Pertanggungjawabannya sendiri, gubernur bertanggung jawab kepada Presiden melalui menteri dan bupati/ walikota kepada menteri melalui gubernur. Hal ini karena gubernur diposisikan sebagai wakil pemerintah pusat. Pendanaan urusan pemerintahan umum sendiri berasal dari APBN. Jadi secara sederhananya, pembagian urusan pemerintahan menurut Undang-Undang No. 23 tahun 2014 tentang Pemerintahan Daerah, terbagi menjadi 3 bagian, yaitu:

Pertama, urusan pemerintahan absolut, ini adalah urusan yang sepenuhnya berada ditangan pemerintah pusat, tapi pemerintah pusat bisa melimpahkan pelaksanaannya kepada daerah sesuai dengan asas dekonsentrasi.

Kedua, adalah urusan pemerintahan konkuren, pengertiannya adalah urusan pemerintahan yang dibagi antara Pemerintah Pusat dan Daerah provinsi dan Daerah kabupaten/kota, urusan yang diserahkan kepada daerah menjadi dasar pelaksana otonomi daerah.

Ketiga, adalah urusan pemerintahan umum, ini adalah urusan pemerintahan yang menjadi kewenangan Presiden sebagai kepala Pemerintahan. Pelaksanaanya bisa diserahkan kepada gubernur atau bupati di daerahnya masing-masing.

\section{B. Kewenangan Pemerintah Daerah dalam mengatur wilayah laut menurut UU No. 23 Tahun 2014 tentang Pemerintahan Daerah}

Undang-Undang Nomor 23 Tahun 2014 tentang Pemerintahan Daerah yang telah ditetapkan untuk mengganti Undang-undang Nomor 32 Tahun 2004 yang tidak sesuai lagi dengan perkembangan keadaan, ketatanegaraan dan tuntutan penyelenggaraan pemerintahan daerah. Muatan UU Pemerintahan Daerah tersebut membawa banyak perubahan dalam penyelenggaraan pemerintahan. Salah satunya adalah pembagian urusan pemerintahan daerah.

Pembagian urusan pemerintahan dalam sistem pemerintahan Indonesia yang dibagi lewat Undang-undang Nomor 23 Tahun 2014 tentang Pemerintahan Daerah salah satu urusan pemerintahannya adalah urusan pemerintahan Konkuren yang dimana urusan pemerintahan yang dibagi antara Pemerintah Pusat dan Daerah provinsi dan Daerah kabupaten/kota.

Urusan pemerintahan konkuren yang diserahkan ke daerah menjadi dasar pelaksanaan Otonomi Daerah, yang menjadi kewenangan daerah terdiri atas Urusan Pemerintahan Wajib dan Urusan Pemerintahan Pilihan. Urusan pemerintahan wajibterdiri atas urusan Pemerintahan yang berkaitan dengan Pelayanan Dasar dan Urusan Pemerintahan yang tidak berkaitan dengan pelayanan dasar.

Urusan pemerintahan konkuren yang kewenangan daerah urusan peemrintahan wajib berkaitan dengan pelayanan dasar yang meliputi: ${ }^{11}$ Pendidikan, kesehatan, pekerjaan umum dan penataan ruang, perumahan rakyat dan kawasan permukiman, ketenteraman, ketertiban umum, dan pelindungan masyarakat sosial.

Urusan Pemerintahan Wajib yang tidak berkaitan dengan Pelayanan Dasar, meliputi: Tenaga kerja, pemberdayaan perempuan dan pelindungan anak, pangan, pertanahan, lingkungan hidup, administrasi kependudukan dan pencatatan sipil, pemberdayaan

${ }^{11}$ Lihat Pasal 12 Undang-undang Nomor 23 Tahun 2014 tentang Pemeintahan Daerah 
masyarakat dan Desa, pengendalian penduduk dan keluarga berencana, perhubungan, komunikasi dan informatika, koperasi, usaha kecil, dan menengah, penanaman modal, kepemudaan dan olah raga, statistic, persandian, kebudayaan, perpustakaan; dankearsipan.

Urusan Pemerintahan Pilihan meliputi: Kelautan dan perikanan, pariwisata, pertanian, kehutanan, energi dan sumber daya mineral, perdagangan, perindustrian, dan transmigrasi. Pembagian urusan pemerintahan konkuren antara Pemerintah Pusat dan Daerah provinsi serta Daerah kabupaten/kota didasarkan pada prinsip akuntabilitas, efisiensi, dan eksternalitas, serta kepentingan strategis nasional.

Penyelenggaraan Urusan Pemerintahan bidang kehutanan, kelautan, serta energi dan sumber daya mineral dibagi antara Pemerintah Pusat dan Daerah provinsi.Daerah kabupaten/kota penghasil dan bukan penghasil mendapatkan bagi hasil dari penyelenggaraan. Penentuan Daerah kabupaten/kota penghasil untuk penghitungan bagi hasil kelautan adalah hasilkelautan yang berada dalam batas wilayah 4 (empat) mil diukur dari garis pantai ke arah laut lepasdan/atau ke arah perairan kepulauan. Dalam hal batas wilayah kabupaten/kota sebagaimana dimaksud pada ayat (6) kurang dari 4 (empat) mil,batas wilayahnya dibagi sama jarak atau diukur sesuai dengan prinsip garis tengah dari Daerah yangberbatasan. ${ }^{12}$

Urusan pemerintahan konkuren yang menjadi kewenangan Daerah provinsi diselenggarakan: ${ }^{13}$

1. Sendiri oleh Daerah provinsi;

2. Dengan cara menugasi Daerah kabupaten/kota berdasarkan asas Tugas Pembantuan atau;

3. Dengan cara menugasi Desa.

Daerah berhak menetapkan kebijakan daerah untuk menyelenggarakan Urusan Pemerintahan yang menjadi kewenangan daerah, dalam menetapkan kebijakan daerah wajib berpedoman pada norma, standar, prosedur, dan kriteria yang telah ditetapkan oleh Pemerintah Pusat.

\footnotetext{
12Lihat Pasal 14 Undang-undang Nomor 23 Tahun 2014 Tentang Pemerintahan Daerah.

${ }^{13}$ Lihat Pasal 20 ayat (1) Undang-undang Nomor 23 Tahun 2014 tentang Pemerinatahan Daerah.
}

Penyelenggaraan Urusan Pemerintahan bidang kelautan, dibagi antara Pemerintah Pusat dan Daerah provinsi yang merupakan salah satu urusan peemrintahan konkuran. Pembagian urusan bidang kelautan dan perikanan dalam Undang-undang Nomor 23 Tahun 2014 tentang Pemerinatahan Daerah diatur dalam lampiran huruf " $Y$ " tentang Pembagian urusan bidang keluatan dan perikanan, meliputi: ${ }^{14}$

1. Bidang Kelautan, Pesisir, danPulau-Pulau Kecil.

Kewenangan Pemerintah Pusat:
a. Pengelolaan ruang laut di atas $12 \mathrm{mil}$ dan strategis nasional.
b. Penerbitan izin pemanfaatan ruang laut nasional.
c. Penerbitan izin pemanfaatan jenis dan genetik (plasma nutfah) ikan antarnegara.

d. Penetapan jenis ikan yang dilindungi dan diatur perdagangannya secara internasional.

e. Penetapan kawasan konservasi.

f. Database pesisir danpulau-pulau kecil. Kewenangan Pemerintah Provinsi:

a. Pengelolaan ruang laut sampai dengan 12 mil di luar minyak dan gas bumi.
b. Penerbitan izin dan pemanfaatan ruang laut di bawah 12 mil di luar minyak dan gas bumi.
c. Pemberdayaan masyarakat pesisir dan pulau-pulau kecil.

2. Bidang Perikanan Tangkap.

Kewenangan Pemerintah Pusat:

a. Pengelolaan penangkapan ikan di wilayah laut di atas 12 (dua belas) mil.

b. Estimasi stok ikan nasional dan jumlah tangkapan ikan yang diperbolehkan (JTB).

C. Penebitan izin usaha perikanan tangkap untuk:

- Kapal perikanan tangkap untuk 30 (tiga puluh) Gross notase (GT)

- Kapal perikanan tangkap dibawah 30 (tiga puluh) Gross notase (GT) yang menggunakan modal asing dan atau tenaga kerja asing.

\footnotetext{
${ }^{14}$ Lihat Lampiran Huruf " $Y$ " tentang pembagian urusan bidang kelautan dan perikanan dalam Undang-undang Nomor 23 Tahun 2014 Tentang Pemerintahan Daerah.
} 
d. Penetapan lokasi pembangunan dan pengelolaan pelabuhan nasional dan internasional

e. Penerbitan izin pengadaan kapal penangkap ikan dan kapal pengangkut ikan ukuran di atas 30 (tiga puluh) GT.

f. Pendaftaran kapal perikanan di atas 30 (tiga puluh ) GT.

Kewenangan Pemerintah Provinsi:

a. Pengelolaan penangkapan ikan di wilayah laut sampai dengan 12 mil.

b. Penerbitan izin usahaperikanan tangkap untukkapal berukuran di atas 5 (lima) GT sampai dengan 30 GT .

c. Penetapan lokasi pembangunan dan pengelolaan pelabuhan Provinsi.

d. Penerbitan izin pengadaan kapal penangkap ikan dan kapal pengangkut ikan ukuran 5 (lima) GT sampai dengan 30 (tiga puluh) GT.

e. Pendaftaran kapal perikanan ukuran 5 (lima) GT sampai dengan 30 (tiga puluh) GT.

Kewenangan Pemerintah

Kota/Kabupaten:

a. Pemberdayaan nelayan kecil dalam daerah kota/kabupaten.

b. Pengelolaan dan penyelenggaraan Tempat Pelelangan Ikan (TPI).

3. Bidang perikanan budidaya.

Kewenangan Pemerintah Pusat:

a. Sertifikasi dan izin edarobat/dan pakan ikan.

b. Penerbitan izin pemasukan ikan dari luar negeri dan pengeluaran ikan hidup keluar wilayah Republik Indonesia.

c. Penerbitan Izin UsahaPerikanan (IUP) di bidangpembudidayaan litas provinsi dan atau yang menggunakan tenaga kerja asing.

Kewenangan Pemerintah Provinsi:

a. Penerbitan IUP di bidang pembudidayaan ikan yang usahanya lintas Daerah kabupaten/kota dalam satu wilayah Provinsi.

Kewenangan Pemerintah Kota/Kabupaten:
a. Penerbitan IUP di bidangpembudidayaan yang usaha berada dalam satu wilayah kabupaten/kota.

b. Pemberdayaan usahakecil pembudidayaan ikan. c. Pengelolaanpembudidayaan ikan.

4. Bidang Pengawasan sumber daya kelautan dan perikanan.

Kewenangan Pemerintah Pusat:

Pengawasan sumber dayakelautan dan perikanan diatas 12 (dua belas) mil, strategisnasional dan ruang lauttertentu.

Kewenangan Pemerintah Provinsi:

Pengawasan sumber dayakelautan dan perikanansampai dengan 12 (dua belas) mil.

5. Bidang Pengelolaan dan Pemasaran.

Kewenagan Pemerintah Pusat:

a. Standarisasi dan pengelolaan hasil perikanan.

b. Penerbitan izin pemasukan hasil perikanan konsumsi dan nonkonsumsi ke dalam wilayah Republik Indonesia.

c. Penerbitan izin usahapemasaran dan pengolahan hasil perikanan lintas daerah provinsi dan lintas negara.

Kewenangan Pemerintah Provinsi:

Penerbitan izin usaha pemasaran dan pengelolaan hasil perikanan lintas kabupaten/kota dalam satu daerah Provinsi.

6. Bidang karantina Ikan, Pengendalian Mutu dan Keamanan Hasil Perikanan

Kewenangan Pemerintah Pusat:

Penyelenggaraan

karantinaikan, pengendalian mutudan keamanan hasil perikanan.

7. Bidang Pengembangan Sumber Daya Manusia Masyarakat kelautan dan perikanan.

Kewenangan Pemerintah Pusat:
a. Penyelenggaraanpenyuluhan perikanannasional.
b. Akreditasi dan sertifikasipenyuluh perikanan.
c. Peningkatan kapasitasSumber Daya Manusia masyarakat kelautan dan perikanan.

Sesuai dengan ketujuh bidang dalam bidang kelautan dan perikanan, kewenangan pemerintah Provinsi dalam mengatur wilayah laut dalam Undang-undang tentang Pemerintahan Daerah Hanya sebatas dalam Laut territorial atau 12 mil sebagaiamana yang ditentukan oleh Undang-Undang. Pemerintah Pusat mempunyai kewenangan diatas laut territorial atau diatas 12 Mil yang berarti 
berada pada Zona Tambahan dan Pemberian izin mengenai kapal ataupun tenaga kerja asing yang bekerja dalam bidang kelautan dan perikanan, serta kewenangan Pemerintah Kabupaten.kota hanya dalam sub bidang perikanan tangkap yang meiliputi pemberdayaan nelayan kecil serta pengelolaan tempat pelelangan ikan (TPI), dan juga sub bidang Perikanan budidaya.

Pemerintah Kabupaten Kota dalam bidang kelautan mendapat kewenanganya berdasarkan tugas pembantuan yang ditugaskan oleh pemerintah provinsi maupun pemerintah pusat, oleh karena itu dalam menjalankan tugas dan kewenangan pemerintah daerah guna mencapai tujuan negara Indonesia, memerlukan efektivitas dan efesiensi dalam menjalankan pemerintahan tingkat provinsi maupun kabupaten/kota sebagai penunjang pemerintahan pusat dan juga berdiri sendiri dalam beberapa hal yang diamanatkan oleh konstitusi dan peraturan perundang-undangan yang berlaku.

\section{PENUTUP}

\section{A. Kesimpulan}

1. Urusan pemerintahan yang menjadi kewenangan Pemerintah daerah Kabupaten/Kota adalah urusan pemerintahan yang lokasinya dalam daerah kabupaten/kota, urusan pemerintahan yang penggunanya dalam Daerah kabupaten/kota, urusan pemerintahan yang manfaat atau dampak negatifnya hanya dalam daerah kabupaten/kota dan/atau urusan Pemerintahan yang penggunaan sumber dayanya lebih efisien apabila dilakukan oleh Daerah kabupaten/kota.

2. Kewenangan Pemerintah Daerah dalam Mengelola wilayah Laut dalam Undangundang Nomor 23 Tahun 2014 tentang Pemerintahan Daerah terdapat 7 (bidang) dalam mengelola dan mengatur wilayah laut yang termasuk urusan pemerintahan konkuren yang dimana urusan pemerintahan ini dibagi kewenangan terhadap pemerintah pusat dan pemerintah daerah, pemerintah pusat dan pemerintah provinsi mempunyai kewenangan dalamketujuh bidang dalam bidang kelautan dan perikanan, kewenangan pemerintah Provinsi dalam mengatur wilayah laut dalam Undang-undang tentang Pemerintahan Daerah Hanya sebatas dalam Laut territorial atau $12 \mathrm{mil}$ sebagaiamana yang ditentukan oleh Undang-Undang. Pemerintah Pusat mempunyai kewenangan mengatur wilayah laut diatas laut territorial atau diatas 12 Mil yang berarti berada pada Zona Tambahan serta Pemberian izin mengenai kapal ataupun tenaga kerja asing yang bekerja dalam bidang kelautan dan perikanan, serta kewenangan Pemerintah Kabupaten.kota hanya dalam sub bidang perikanan tangkap yang meiliputi pemberdayaan nelayan kecil serta pengelolaan tempat pelelangan ikan (TPI), dan juga sub bidang Perikanan budidaya.

\section{B. Saran}

Penulis menyarankan agar kewenangan mengenai pengelolaan dan pengatur wilayah laut diserahkan secara merata sesuai dengan asas-asas umum pemerintahan yang baik terhadap pemerintah kabupaten/kota, meskipun pemerintahan kabupaten/kota bisa menjalankan tugas atas perintah pemerintah pusat maupun provinsi dalam mengatur wilayah laut tetapi hanya sebatas tugas pembantuan semata. Pemerintah kabupaten/kota sebagai wilayah otonom juga berhak untuk mengatur wilayah laut yang masuk dalam wilayah kabupaten/kota tersebut agar digunakan sebagaimana mestinya dan juga berpotensi menjadi salah satu pendapatan daerah khususnya kabupaten/kota yang tidak dibagi hasil kelautan dan perikanan dengan pemerintah provinsi.

\section{Buku dan Jurnal}

\section{DAFTAR PUSTAKA}

Alamsah D, Nandang, 2017, Teori \& Praktek Kewenangan, Jakarta. Pandiva buku.

Amrusi, Fahmi, dan Huda, Ni'matull, 2012,Hukum Pemerintah Daerah, Bandung: Nusamedia

Basri, Penataan dan pengelolaan wilayah kelautan, Vol XVIII No. 3, 2013. 
Bariun, La Ode, 2015, Hakikat Kewenangan Mahkamah Konstitusi Dalam Penyelesaian Sengketa Hasil Pemilihan Kepala Daerah Yang Berkeadilan. Makassar: Disertasi. Program Pasca Sarjana. Universitas Hasanuddin.

Bromley, Daniel W dan Cernea, Michael World Bank Discussion Papers, The Management of Common Property Natural Resources.

Cipto Handoyo, B Hestu, 2015, Hukum Tata Negara Indonesia, Yogyakarta: Cahaya Atma Pustaka, Yogyakata.

Gayo, H.M. Iwan. 2000. Upaya Warga Negara. Jakarta: Buku Pintar. Seri Senior.

Haryono, Harry, 2009, Wilayah Udara Indonesia: Sudahkah Kita Memanfaatkan dan Menjaganya", Jurnal Hukum Indonesia, volume 6

Huala, Adolf, 1990,Aspek-Aspek Negara dalam Hukum Internasional, Jakarta: PT RajaGrafindo.

I. K, Syafiie, 2011. Pengantar IImu Pemerintahan. PT. Refika Aditama.

J.L, Brierly, 1996, Hukum BangsaBangsa.Jakarta: Bhratara

Kusdarini, Eny, 2011,dasar-dasar Hukum Administrasi Negara dan AsasAsas Umum Pemerintahan yang Baik, Yogyakarta: UNY Press.

Lidkadja, Frans dan Bassie, Daniel, 1985, Hukum Laut Dan Undang-Undang Perikanan, Jakarta: Ghalia Indonesia.

Muthalib Tahar, Abdul,2007, dalam Diktat Hukum Laut Internasional menurut $\quad K H L \quad 1982$ danPerkembangan Hukum Laut di Indonesia pada Bagian Hukum Internasional Fakultas Hukum, Unila.

Retnami, SetyaMakalah Sistem Pemerintahan Daerah di Indonesia, 2001

Ridwan HR, Ridwan, 2013,Hukum Administrasi Negara, Jakarta: PT Raja Grafindo Persada

Sarundajang, 1999,Arus Balik Kekuasaan Pusat ke Daerah,Jakarta: Pustaka Sinar Harapan.
Winamo, Basuki Nur, 2008, Penyalahgunaan Wewenang dan Tindak Pidana Korupsi, Yogyakarta: laksbang mediatama.

\section{Peraturan Perundang-undangan \\ Undang-Undang Dasar Negara Republik Indonesia Tahun 1945 \\ Undang-undang Nomor 4 Prp Tahun 1960, tentang Perairan Indonesia \\ Undang-undang Nomor 23 Tahun 2014 Tentang Pemerintahan Daerah \\ PP Nomor 4 Tahun 2018 tentang Pengamanan Wilayah Udara RI.}

\section{Referensi Lainnya}

United Nation Convention on the Law of the Sea 1982

www.id.wikipedia.org, 9 Juni 2019 "Deklarasi Djuanda"

http://www.thejakartapost.com/news/2014/12 /22/overcoming-problems-newautonomy-era.html.

http://digilib.unila.ac.id/11139/3/BAB\%20II.pdf

www.id.m.wikipedia.org, 9 November 2018 "Daratan".

www.id.m.wikipedia.org, 16 November 2019 "Indonesia". 